\title{
DIVERSIFYING URBANITY: THE JAPANESE COMMERCIAL COMMUNITY OF PRE WORLD WAR II MANILA
}

\author{
Augusto V. de Viana
}

\begin{abstract}
Starting from a small group of transient peddlers and workers early in the $20^{\text {th }}$ century, Manila's Japanese commercial community became a diverse group of businessmen whose establishments contributed to the character of the city. Internal and external factors were responsible for the growth of the Japanese community in Manila that by the 1930s the commercial community numbered 250 establishments ranging from small shops to branches of big Japanese corporations such as Mitsui Bussan and Daido Boeki Kaisha (today's Marubeni Corporation). Though the Japanese commercial community in the $20^{\text {th }}$ century was a recent arrival and it was small compared to the communities of other nationalities its businessmen showed exceptional acumen that by the 1930s many things that a Filipino bought or ate passed through a Japanese merchant. Sections of Manila became known as "Manila's Ginza" and "Little Tokyo" because of the presence of many Japanese establishments. As the decade of the thirties approached the 1940s the foreign community especially those of the Japanese faced the challenge of rising Filipino economic nationalism caused by the sentiment over the foreign domination of the Philippine economy. Instead of crumbling to the pressure the Japanese commercial community did not just survived but continued its expansion as it addressed the threats to its existence and it was prepared to defend its rights and gains through any means possible including force if necessary. This paper discusses the reasons for the growth of the Japanese businesses in Manila during the first four decades of the $20^{\text {th }}$ century. It also discusses how the behavior of the Japanese commercial community in the context of rivalry between the United States and Japan and the rising Filipino nationalism.
\end{abstract}

\section{Introduction: The Reentry of Japan to the Philippines}

Japan's isolation ended in 1854 following the Treaty of Kanagawa opening Japan to American commerce. Official relations between colonial Philippines and Japan however did not resume until 1888 when the Japanese opened their consulate in Manila. The reentry of Japanese to the Philippines was very slow because of high tariffs imposed by the Spaniards and the unstable local currency. Other factors were the difficulty of the Japanese in communicating with the Filipinos and Spaniards and the influence of the Catholic Church. ${ }^{1}$ When the Japanese consulate began operating in Manila it listed 35 Japanese residents including four consular staff members. Of the 35 twelve were entertainers and 15 were sailors. In 1890 there were only two Japanese in Manila and both of them were consulate personnel. All the Japanese residents of Manila at that time were transients and because of the negligible amount of Japanese nationals in the country Japanese consulate was forced to close down in October 1893. All diplomatic concerns of Japan in the Philippines were handled by the consulate in Hong Kong. In the same year there were 33 Japanese obreros electricistas (electricians) listed in the Radicacion de Extranjeros as residents of Manila. These electricians were sent by the Yokohama Trading Company to install electric wires in the city. Aside from the electricians there were also five commerciantes (businessmen) and five carpenters. According to the Radicacion de Extranjeros most of them lived in No. 16 Uli-Uli Street in San Miguel, Manila. The address according to Wada was probably a dormitory or an apartment which accommodated such a number of persons. There was also an ironsmith 
(herrero) and two cooks living in 54 Calle Nueva in Binondo and two plumbers (fontaneros). ${ }^{2}$

Aside from the Japanese workers the first permanent Japanese commercial establishment, the Nippon Bazar was opened at Plaza Moraga in Binondo district in 1893. The bazaar was originally a joint venture of Tsurujiro Kimura and Shintaro Fukuchi and later operated by Seitaro Kanegae in $1898 .^{3}$ The bazaar became historically famous as the venue of a meeting by top officials of the secret pro-independence secret society called the Katipunan and Japanese navy officers on March 1, 1995. During that meeting the Katipunan representatives led by Emilio Jacinto asked for help from Japan by supplying them with arms which will be used to overthrow the Spaniards.

The Nippon Bazar was followed by Osaka Bazar which was also located in Plaza Moraga in Binondo. By the time when the Philippine Revolution broke out in August 1896, there were other Japanese stores established in Manila. These were the Kaigai Boeki Kaisha, the Iijima Shoten, the Oi Bokushin and the Tagawa Shoten. However out of these establishments only the Nippon Bazar and the Tagawa Shoten stood out in terms of the items sold. Tagawa formerly worked with the Nippon and Osaka Bazars before starting his own store. He carefully studied by buying habits and preferences of the Filipino customers which allowed his business to prosper.

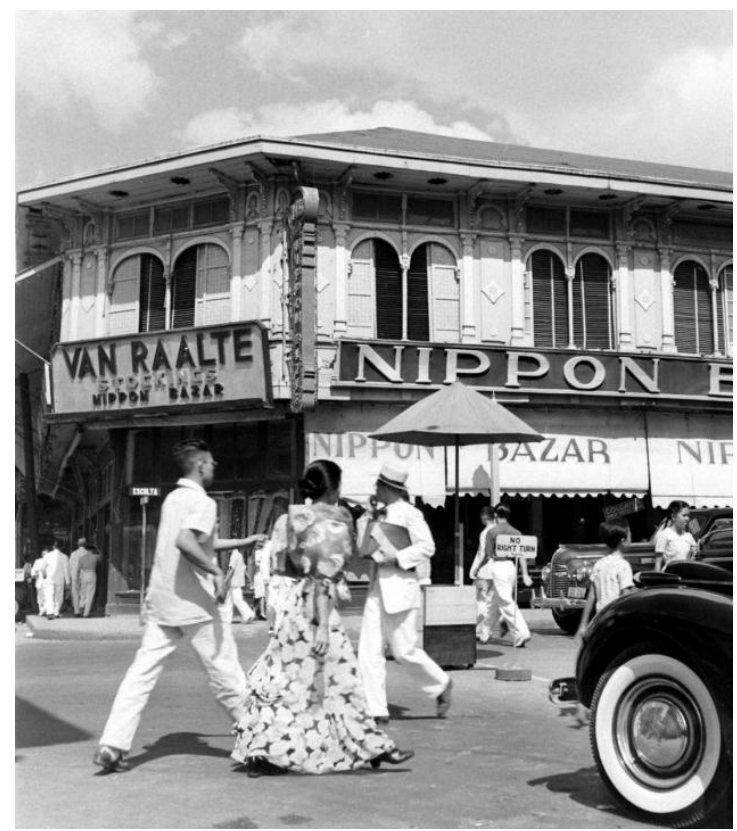

The first Japanese bazaar,the Nippon Bazar continued it existence until the Second World War.

Aside from the stores there was one report that the Japanese entered the brothel business. In 1898 one Japanese brothel was officially reported in Carriedo Street in Manila. The brothel had a coffee shop as a front and had two women who arrived from Nagasaki who arrived in Manila via Singapore and Iloilo. The Japanese consul denied that there were Japanese brothels in Manila. ${ }^{4}$ Before the influx of Japanese women, foreign prostitutes such as those from Russia and France came to Manila. In 1899 four Japanese women arrived from Hong Kong and were initially refused to land because they looked like prostitutes. Two were allowed to stay in Manila when they showed proper travel documents and evidence that they could support themselves while they were in the Philippines. The other two were sent back to Hong Kong. In the same year Japanese prostitutes were reported plying their trade in the Sampaloc district and there was one incident involving an American corporal who was 
arrested because he struck a Japanese woman and dragged another by the hair because they refused to serve him beer "in a house of ill fame." 5

As American rule became more stable the Americans embarked on several public works projects which demanded skilled labor especially for infrastructure. The economic hardships in Japan caused by the devaluation of the Japanese yen following Japan's involvement in the Sino-Japanese War in 1894-1895 and the Russo-Japanese War in 19041905 caused an exodus of impoverished Japanese abroad including the Philippines. The Japanese community of Manila continued to grow from a few handful in 1899, 107 individuals were reported in 1900; by 1903 there were 920 and in 1904 it grew to 2,770.

In 1903 Col. Lyman Kennon who was building the Benguet Road brought in 800 Japanese workers from Okinawa. Kennon needed the Japanese workers to replace the Filipino and Chinese workers who could not withstand the rigors of the mountain climate. The 800 workers number eventually grew to 1,500. Of that number around 800 workers survived and the rest died from accidents and disease while building the road. Of this number around 250 to 300 opted to stay in the Philippines after finishing the road. Some of them became settlers in Davao while a few went to Manila to become artisans, cabinet makers and workers in trades that the Filipinos themselves could not supply. They were joined by other Japanese immigrants who opened businesses such as laundry shops, bakeries, candy factories and dry goods stores. Others found employment as gardeners, carpenters and mechanics. Through sheer industry and hard work the Japanese community in Manila was able to build up a reputation among the Filipinos and the Americans. ${ }^{6}$

At this point most of the Japanese who came to the Philippines in the first decade of the $20^{\text {th }}$ century were transients. After earning enough money they would return to Japan. Their common dream was "Save money, go back to Japan, marry a Japanese lass even though I have reached the age of forty." According to Kiyoshi Osawa who came to the Philippines in 1925 , many of his countrymen clung to such dreams. ${ }^{7}$

Other Japanese immigrants shifted from being laborers and carpenters to become merchants and shop owners. This was a significant aspect because the Japanese immigrants were always artisans and craftsmen. They became itinerant vendors who sold ice cream cones and products such as barquillos or sugar wafers. One of the most successful of these immigrants was a street peddler named S. Awata who carefully studied the needs of Filipino consumers. Soon he became a store owner and other merchants sold all kinds of Japanese goods. Originally Japanese stores catered to the immigrant Japanese community but soon began appealing to Filipino consumers. They learned that Filipinos demanded goods that look good but were sold at very low prices. In a random interview of a Filipino consumer by an American journalist in 1937 the Filipino said:

A Filipino worker cannot afford to pay one peso or two pesos for a shirt made in your country (the United States). He wants a Japanese-made shirt which he can get for only 30 or 40 centavos. $^{8}$

The great difference between the labor costs and manufacturing costs allowed the Japanese merchants to undersell the Chinese and Filipino competitors. The Japanese even had a system of delivering the goods to their buyers. Between 1902 to the outbreak of the First World War in 1914 Japanese stores grew from a small handful to around 20 in 1914. Though the Chinese continued to dominate the retail trade the share of Japanese stores continued to increase from $5 \%$ in 1930 to $20 \%$ in $1938 .{ }^{9}$ 


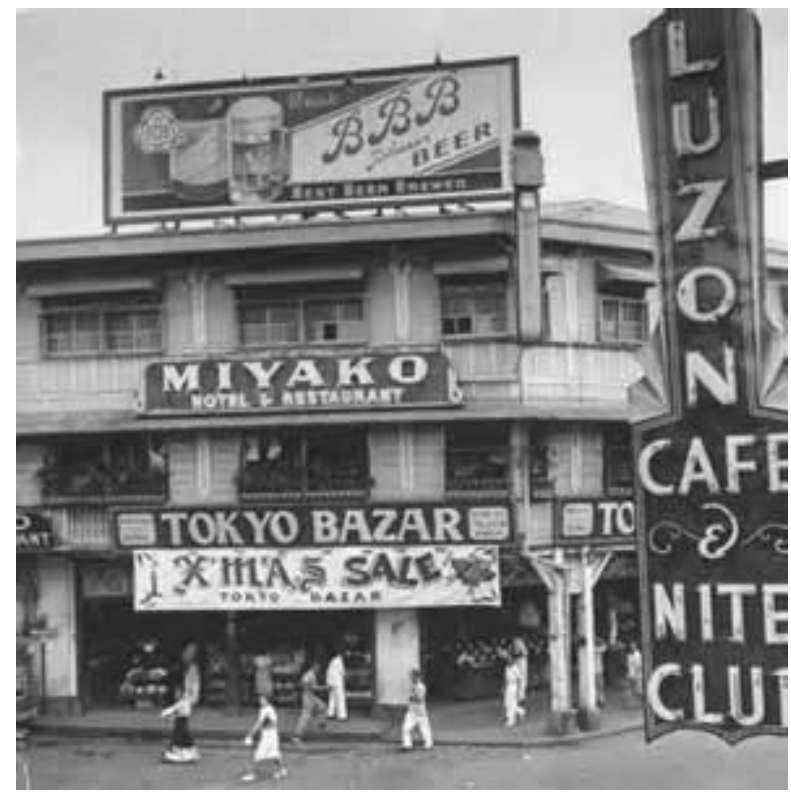

A Japanese bazaar with a hotel and restaurant in Manila.

Note also the advertisement of the beer brand which was also managed by Japanese businessmen.

With the influx of more Japanese immigrants the Japanese government upgraded its consulate in Manila to that of a consulate general in 1919. It moved its location from the sleepy area of Manila to the Wilson Building in Binondowhich was the business center of Philippines. At that time there were 2,068 Japanese residents in Manila out of a total of 9,800. The Japanese in the Philippines comprised $42 \%$ of all Japanese in Southeast Asia. ${ }^{10}$ The Japanese government supported semi-government organizations to protect Japanese interests in the Philippines. One of these was the Nanyo Kyokai or the Philippine Society of Japan which had its office at the Overseas Branch of the Taiwan Governor General's Office in Tokyo. The Philippine organization was the Firipin Kyokai and its first President was Consul General Ichiro Nuida. ${ }^{11}$

\section{Problems Encountered}

Like any foreign community, the Japanese community of Manila had its own problems. The most prominent of these problems was prostitution. Generally Japanese men did not bring their families with them when they went to the Philippine and many of them patronized brothels. The economic hardship in Japan caused a proliferation of brothels in Manila.

Before 1909 the red light area of Manila was in Escolta Street which served as the rest and recreation area for US troops. The street was lined up with saloons which were later transferred by Governor Dwight Davis to Sampaloc district. The brothels were concentrated at Gardenia Street also in Sampaloc. In 1909 there were around 30 brothels and 300 prostitutes. Residents in the area who were then children recalled that there were many Japanese women wearing kimonos at the verandas of the old Spanish-style houses. Soon the brothels sprouted to other areas like Calle Alix, Balic-Balic and Sulucan. There were also brothels in San Miguel, Quiapo and Santa Cruz districts.

The Japanese prostitutes were called Karayuki-san which is a $19^{\text {th }}$ century term from "Kara" which referred to China and "yuki" which is a suffix for persons going to a certain place. At the time Japanese women who went to China were called Karayuki. Later the term referred to women who went abroad to become prostitutes. Most of the Japanese girls came from Kyushu and recruiters often deceived girls from poor Japanese families about nonexistent jobs in the Philippines. The recruiters connived with officers of ships to smuggle the 
girls in the Philippines and upon arriving in the islands the recruiters would charge the girls exorbitant fees to cover hotel expenses, transportation costs and entrance fees. Once the girls earned enough money they would send part of their earnings to Japan. The village head would know about the good news and would lose no time to charge income tax. In this way prostitution helped increase the national coffers.

Whenever a brothel was established other businesses' followed. The brothel industry fuelled other businesses. These included bazaars which filled the need for Japanese dry goods as well as restaurants. The other businesses were photography shops, boarding houses and hotels. The brothel industry also supported trades such as kimono-making, tailors and dressmakers of Western-style clothes. Seitaro Kanegae of the Nippon Bazar specifically mentioned that some of the bazaars depended on the brothel industry. ${ }^{12}$ He mentioned the Matsui, Fukuda, Noguchi, Mahui, Sonoda bazaars, the Ogawa Watch Shop, the Aoyama Photo Studio, the Fujimoto Barbershop and a number of hotels, restaurants and refreshment parlors.

There was a high incidence of crime in areas in the brothel areas. Male Japanese lived a life of crime by swindling, gambling and heavy drinking. Stabbings were common as the men organized themselves into gangs. Venereal diseases were rife that even the US Army became concerned because it needed men who were physically fit as the United States had just entered the First World War On October 16, 1918 the Mayor of Manila took drastic measures by cordoning off the red light district at Gardenia Street and raided all prostitution dens. The Japanese men and women who were caught inside the prohibited zone were arrested and deported while the Filipino prostitutes were also rounded up and sent back to their home provinces. The round-ups and deportations lasted until 1925. Some Japanese women avoided deportation because they were married to Filipinos. The Japanese community developed a term for the former Japanese prostitutes who survived the crackdown and shifted to more a more decent livelihood as thedaigakude or college graduate. Some of these daigakude became owners and operators of restaurants and hotels in Manila.

While Mayor Lukban was praised for his campaign of cleaning the city of brothels, he was chided by the Supreme Court for arbitrarily violating due process and the rights of the Filipino and Japanese women. Though most of the Japanese prostitutes were gone after the First World War, the Japanese women who remained even if they were never prostitutes risked humiliation by Chinese and Filipinos who believed that all Japanese women in the Philippines were Karayukis. This condition forced Japanese men to confine their women at home for fear of being insulted. It reinforced the perception by the Filipinos that the Japanese were an aloof people and cannot be assimilated into Filipino society.

The reaction of the Japanese diplomatic officials to Mayor Lukban's crackdown was to support his campaign. Since many of the Japanese immigrants were undocumented aliens and were not registered with the Consulate General, diplomatic officials cannot protect them whenever the Manila police took action against their illegal activities. As early as 1907 the Japanese consul even cooperated with the police in banishing his troublesome countrymen to Japan. ${ }^{13}$

Many of the early Japanese immigrants were poor and uneducated and many of their small shops such as refreshment and massage parlors which were often fronts for illegal activities like prostitution. A number of Japanese men married to Filipino women were seen as violent, cruel and miserly. Often they used their marriage to their wives to circumvent Philippine laws by using their wives' names to acquire land. The educated ones hired lawyers and formed friendly ties with Filipino politicians.

The Japanese government took steps to cultivate friendly relations with the Filipinos by minimizing irritants. It established a Bureau of Industries in Manila to help Filipino firms doing business with Japanese companies and a Japan Information Bureau was created to 
manage a school that taught the Japanese language to Filipinos. The bureau also operated a library for Filipinos and sponsored educational trips to Japan for students, newspapermen and politicians.

\section{Continued Growth and Increasing Diversity}

With the end of World War I, the number of Japanese business establishments continued to grow as more Japanese immigrants came to the Philippines. From 8,000 immigrants in 1918 the number swelled to 20,262 in 1939. In Manila there were 1,612 Japanese in 1918, in 1930 the population reached 3,984. With the increase in the number of Japanese residents so did the business establishments. In 1914 there were 41 Japanese-owned bazaars, 21 trading firms and numerous small shops and refreshment parlors. There were also 73 registered businessmen, bank clerks and 104 store employees. By 1931 there were 243 Japanese businessmen and by 1936 there were a total of 303 establishments registered. ${ }^{14}$

In studying these Japanese business establishments a wealth of anecdotal information can be found. One such story is about the Eigetsu Hotel in Santa Cruz which was owned by a daigakude or former Karayuki who can still be seen in her kimono. Another establishment was the Sakura Restaurant owned by another daigakude named Mitsu Shimizu who was described by Osawa as the Amazon and female knight of the town because of her feistiness. Mrs. Shimizu had a maiko or geisha apprentice named Osato-san working for her. Osato-san played the samisen before the customers and loved to tell the classics. According to Mr. Osawa Osato-san was the only woman among Manila's 5,200 residents who can be rightfully called a geisha. ${ }^{15}$

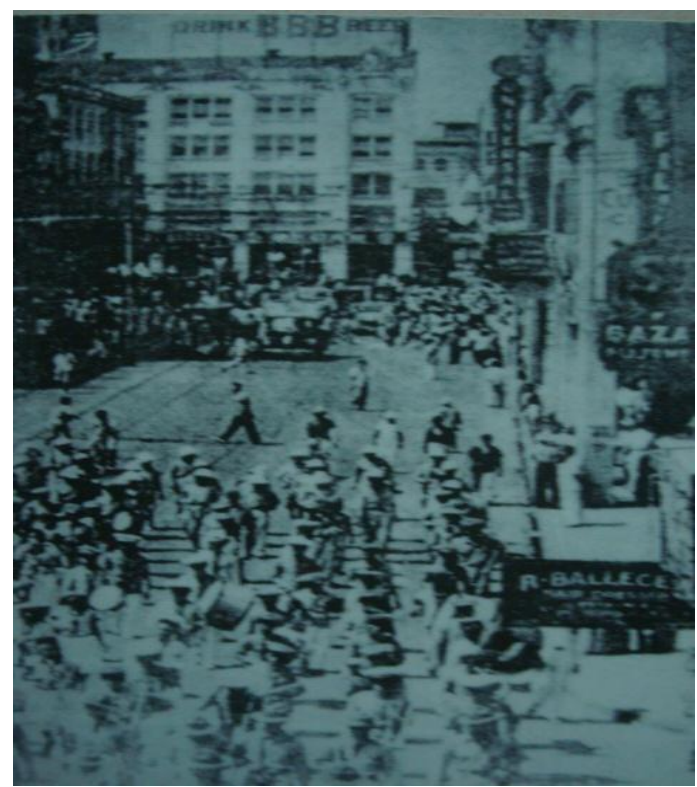

Rizal Avenue in Manila, Manila's main street which was part of Manila's Little Tokyo because of the presence of many Japanese businesses.

One business the Miyazaki Garden became famous for breeding and exporting its own brand of orchids. Other businesses that stood out were the Sun Studio owned by Mr. T. Yamamoto which produced excellent portraits. Another was the Sun Studio made photographic postcards some of which portrayed beauty pageant winners in the annual Manila Carnival. Another studio was the Triangulo Studio which was a pioneer in covering weddings and parties. ${ }^{16}$

The Japanese residents of Manila also managed a number of massage parlors, many of which were managed by women. In the Rosenstock's Directory of Manila a number of 
massage shops carried information that the shops were owned and run by women. There were barbershops owned by Japanese and girls were employed as barbers.

Behind the Japanese bazaars and the retailers were the big trading firms. The oldest firm which did business in the Philippines was the Mitsui Bussan Kaisha which had its headquarters in Rosario Street in Binondo, Manila. It entered the Philippines in 1898 and it supplied coal from the Miike mines in Kyushu. At first the company did not even have a branch office in the Philippines and it was actually based in Hong Kong. Later it established a representative office at No. 32 Plaza Moraga at the second floor of the building that housed the Nippon Bazar. The Mitsui Bussan outlet was involved in the importation of coal, cotton, wax and cement from Japan. Its biggest customer for the coal business was the US Navy and the coal importation venture was its biggest venture. The company also exported Philippine abaca, cigars, sugar and copra to Japan. Later Mitsui diversified into dry goods distribution, steamship services, distribution of matches, fertilizer, cement, cigar, copra, coal and abaca, insurance and automobile dealership. In 1937 it became a part-owner of the Tagum Logging Company in Davao. ${ }^{17}$

The second giant Japanese company was the Daido Boeki Kaisha which was based in Kobe, Japan. It was involved in the importation of hardware goods and specialty products sold in Japanese bazaars. The company had its offices at the Hong Kong and Shanghai Bank at Juan Luna Street in Binondo and it had branch offices in Cebu, Iloilo and Davao. Daido Boeki handled the importation of iron and steel products like iron and steel rods for the construction industry. It operated a hardware store which sold Asano Portland Cement, Yamnar Diesel engines and Bridgestone tires. It imported and sold farm equipment, celluloid goods, all kinds of metals, onions and wheat flour, automobiles, and musical instruments while it exported scrap iron, maguey, fish and fish products, abaca, copra, kapok seeds, corn, fish products, trochus shells and mineral ores. ${ }^{18}$ Another big trading company was the Osaka Boeki Kaisha which also operates the Osaka Bazar as its retail outlet. It distributed Kikkoman soy sauce, Pilot pens and Kurokami hair dye.

Japanese shipping firms had their offices in Manila. The oldest of these was the Nippon Yusen Kaisha (NYK) or the Japan Shipping Line. It was the pioneer in the Philippine-Japan shipping route. It started sailing to Manila from Kobe and its ships regularly connected the Philippines to Nagasaki, Kobe and Yokohama to the Chinese ports of Hong Kong and Amoy and those of Taiwan. It carried not only cargo but also passengers. Other Japanese shipping firms were the Osaka Shosen Kaisha and the Ishihara Sangyo Kaisha. The big Japanese trading companies also had their own shipping companies such as the Mitsui Bussan Kaisha and the Mitsubishi Shoji Kaisha which carried passengers and cargo across the oceans.

The growth of the Japanese commercial community in Manila would not be possible without the role of the Japanese financial institutions. The largest of these institutions was the Yokohama Specie Bank which was also known as the Yokohama Shoten Ginko. It had a capital of 100,000,000 yen and an additional reserve of 131,000,000 in 1935. Supplementing the Yokohama Specie Bank was the Bank of Taiwan which was based in Taihoku. Both banks provided valuable financial support to Japanese businesses in Manila. That support enabled these businesses to later expand into manufacturing, mining and lumber. ${ }^{19}$

There were also a number of Japanese mutual aid associations or tanomoshiko which provided financial support to various Japanese businesses. Among them were the Japanese Mutual Loan Association, the Manila Japanese Mutual Loan Association and the Manila Ko Sei Kai. Aside from providing financial support the last secured jobs for its unemployed members and it operated a dormitory for those who were temporarily unemployed. ${ }^{20}$ 
The advertisements of some Japanese businesses in Manila

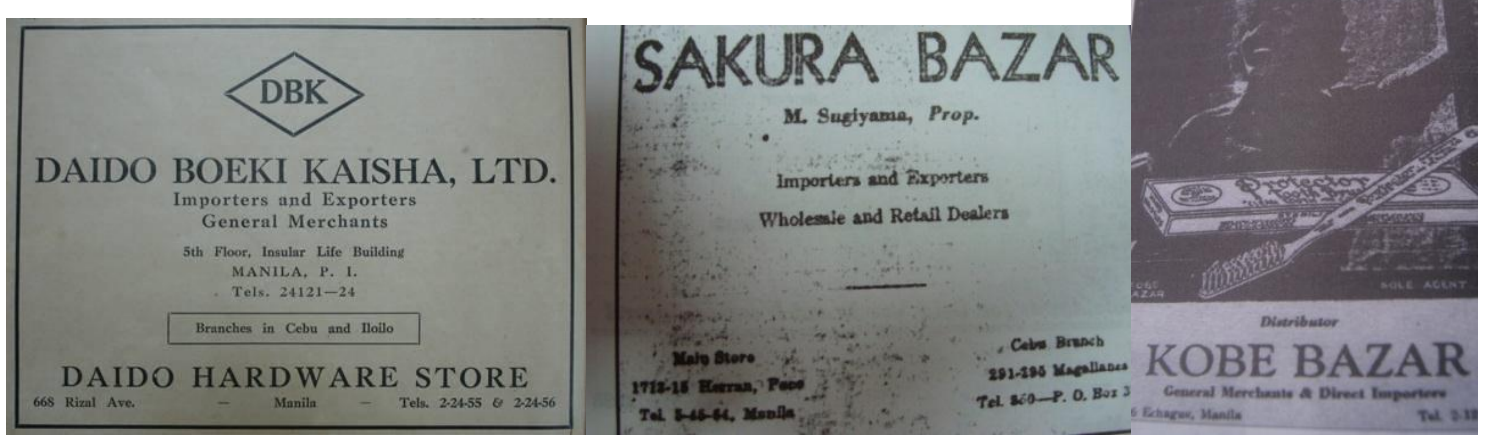



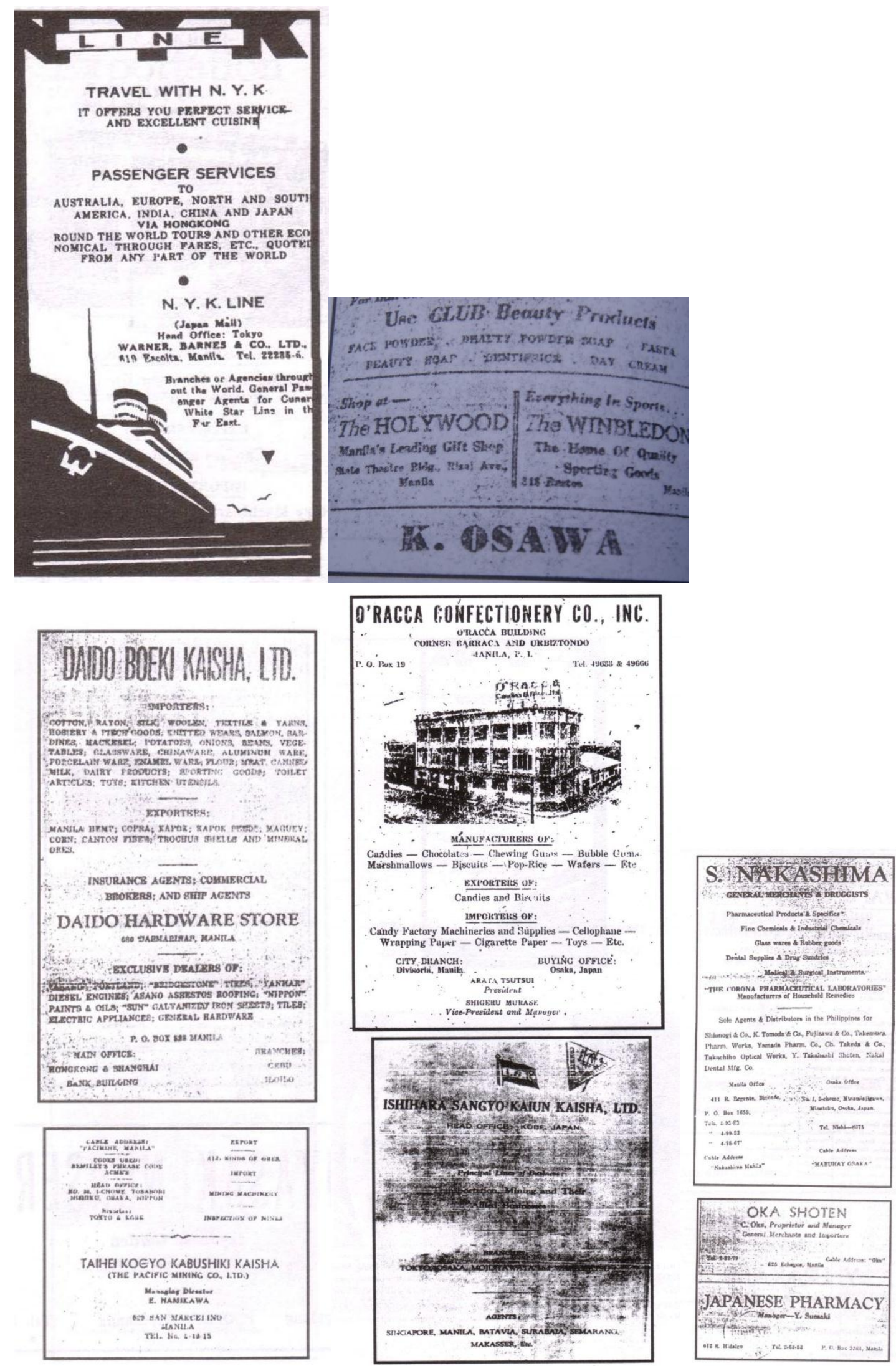


\section{Reactions to the Growth of Japanese Businesses}

Though the Filipinos generally welcomed the Japanese as well as other foreigners there was a sense of wariness towards outsiders as a result of a rising nationalist sentiment. This sentiment was stirred up by demagogues who questioned the foreign domination of the Philippine economy. Writing in the newspaper Sakdal, the Tagalog poet Benigno Ramos wrote:

Wouldn't it gladden us if it could be said that the whole stretch of Escolta is owned by Filipinos. Rosario (Street) is not for the Chinese, but for our countrymen. Rizal Avenue, is not for the Japanese, but for our own?

Though these words were not aimed directly at the Japanese but to foreigners in general, Ramos felt that it should be the Filipinos who should benefit from the economy not the foreigners. Another sign of rising economic nationalism was the prohibition under the 1935 Constitution limiting foreign capital in any business to only $40 \%$ while Filipino capital should be at least $60 \%$. Following the inauguration of the Philippine Commonwealth in 1935 the legislature passed laws designed to limit the activities of foreigners. Commonwealth Act No. 100 or the Forestry Act made it illegal for foreigners to engage in logging; Commonwealth Act No. 118 required that three fourths of crewmen of fishing boats must be Filipino and Commonwealth Act No. 141 or the Public Land Act. The law made it impossible for foreigners to acquire land in the Philippines. In 1939 the legislature passed the AntiDummy Law which provided punishment for Filipinos who allowed themselves to serve as fronts by foreigners. It was intended to curb the practices of foreigners in putting the names of their businesses in the names of their Filipino partners. The Immigration Act of 1940 restricted to 500 individuals of every nation who can immigrate to the Philippines. There was also a bill restricting retail trade to Filipinos.

Before most of these nationalist measures were enacted the Japanese commercial community already weathered the challenge by the Chinese who launched a boycott of Japanese businesses following Japan's invasion of China in 1937. Instead of collapsing following the refusal of Chinese traders to carry Japanese goods, the Japanese sourced the goods themselves.

In responding to the challenges imposed by Filipinos the Japanese showed extraordinary resilience and flexibility. Many Japanese took steps to becoming Filipino or American citizens. The Japanese government urged their countrymen to learn the Tagalog language in anticipation that this dialect might become the national language. The problem of the fishermen was circumvented by putting the permit for the fishing boat in the name of a Filipino and though the Filipino crew might were paid by the Japanese boat owner. ${ }^{21}$

In anticipation that the import trade might be restricted to Filipinos, many Japanese firms shifted their operations into manufacturing. One of the biggest investments of the prewar era was the establishment of the Balintawak Beer Brewery in Polo, Bulacan. The brewery was built with capital from Mitsui Bussan and other Japanese investors. Mitsui also invested in a shoe factory and numerous factories manufacturing shirts were established. Among them were the Kinkwa Meriyasu Factory, the Noguchi Factory, the Toyo Shirt Factory, the Tomonaga Shirt Factory and the Rex Shirt Factory. There was even a candy factory, the O' Racca Confectionery factory which became the islands' biggest candy factory and importer of sweets. The Mori Bicycle Factory began turning out bicycle frames though most of its components came from Japan.

Most of all the Japanese took pains to befriend Filipino politicians and secure the services of their best lawyers. Among these politicians were Jose P. Laurel, Claro M. Recto and Quintin Paredes. These politicians would later serve as collaborators during the Japanese 
occupation. Seeing that many actions of the Philippine Commonwealth actually had in mind, many Japanese were prepared to use force if necessary to protect their gains in the Philippines. $^{22}$

The Japanese could have adapted well in the face of the challenges if not for the outbreak of the Second World War in the Philippines. After bombs were dropped on Manila business establishments including those of the Japanese were ransacked by mobs. Two hundred ninety Japanese residents including Mr. Osawa were rounded up and taken to the Old Bilibid Prison and later to the New Bilibid Prison. But as the Japanese military began to approach Manila, they were taken to the Manila Japanese School where they were freed by the Imperial Army.

With the ransacking of the Ginza of Manila and Manila's Little Tokyo as Osawa described the jewels of the Japanese commercial community of Manila were no more. Though many Japanese businesses resumed operation at the beginning of the Japanese occupation the luster of the old Ginza was gone. During the war many Japanese residents were forced to serve as guides and interpreters for the Imperial Forces. When the Americans returned in February 1945, 70\% of Manila was razed to the ground by artillery and fire. Thousands of Japanese were killed in the campaign to retake the Philippines.

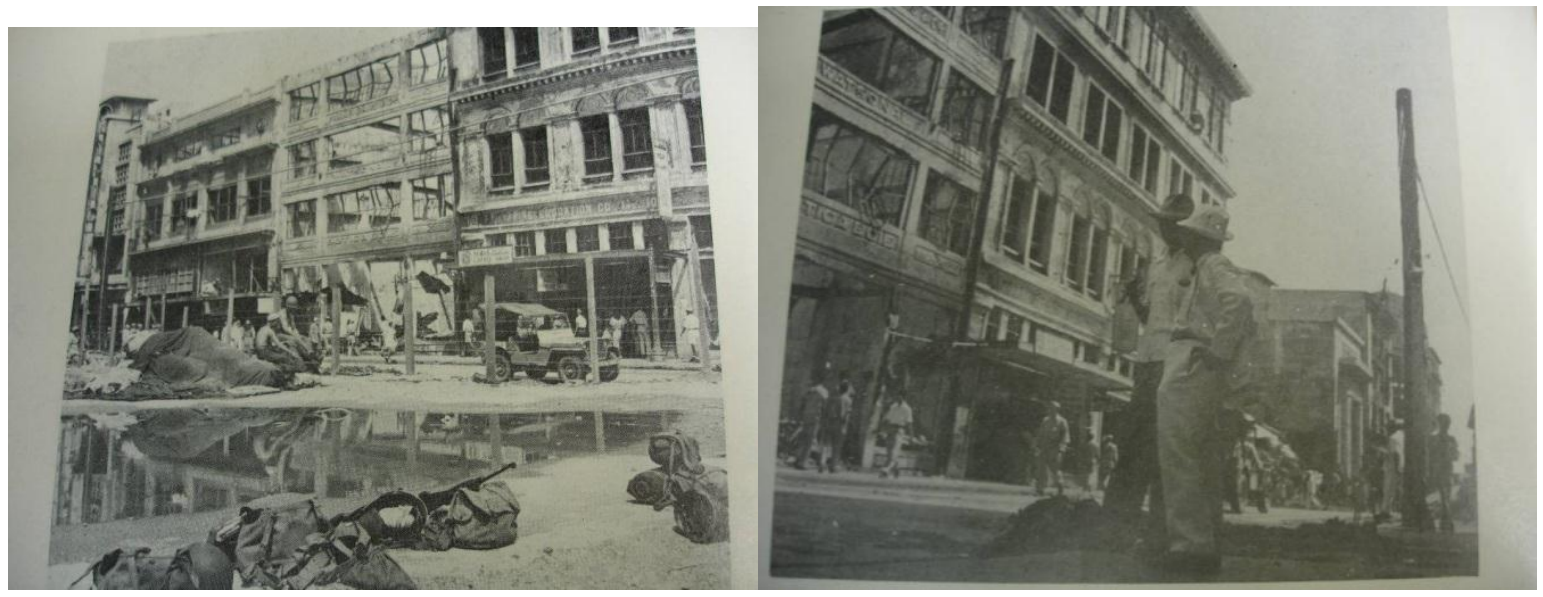

What was left of the Ginza of Manila in Escolta Street, March 1945.

At the end of the war, the surviving Japanese civilians were interned at the Old Bilibid Prison in Manila. Later they were transferred to a camp in Cabuyao. In November 1945 they were ordered to be repatriated to Japan. A number of internees did not wish to go back to Japan since they have lived in the Philippines most of their lives. About a hundred made a petition to remain in the country. They were warned however if they stayed they might be killed by Filipinos. ${ }^{23}$ That month they were taken to the pier of Manila and sent back to Japan. It would take until 1968 when normal relations between the Philippines and Japan were restored but by that time the old prewar Japanese commercial community of Manila can never be replicated as their former sites were taken over by the Chinese, the Filipinos and the Philippine government.

\section{Conclusion}

The first three decades of the $20^{\text {th }}$ century witnessed the growth of the Japanese community of Manila after it had been suppressed by more than two centuries of self-isolation. The formation and growth of this community was caused by economic and political factors both in Japan and in the Philippines. For the Japanese the economic hardship faced by their country at the beginning of the century forced them to look beyond their shores. The Philippines presented an economic opportunity. The will be able to work in the islands and 
send their earnings back to Japan. The Philippines on the other hand needed the expertise of the Japanese especially in road building and infrastructure.

Towards the third decade of the $20^{\text {th }}$ century the Japanese commercial community began to expand and its presence became more permanent. There was an evolution from the itinerant businessmen to a more established enterprises as Japanese immigrants set up permanent businesses such as shops, hotels, bazaars and parlors. Outside of Manila plantations managed by Japanese continued to expand. To the Japanese the Philippines was their land of opportunity and at the same time they contributed to the urban diversity of Manila.

Though numbering only around 5,000, Japanese presence was felt by Filipinos in general. It could be said that whatever any Filipino bought, ate or wore passed through a Japanese trader. Aggressive marketing and research about Filipino buying habits led to the growth and expansion of the Japanese commercial community. Parts of Manila were "Japanized" with the presence of many Japanese businesses. More importantly the Japanese business gave Filipino consumers a freedom of choice.

However rising nationalist sentiment among Filipinos caused wariness against the foreign community and the Japanese community was included in this rising tide of nationalism. The fear of Japanese domination was coupled with the fear of a military invasion from Japan in the late 1930s and into the 1940s. Instead of buckling down however the Japanese community showed exceptional reliance and flexibility by studying Philippine laws and devised ways of dealing with legal restrictions. They developed friendships with Filipino politicians and hired lawyers who may help them in protecting their gains. The even contemplated in using force if necessary.

The coming of the Second World War to the Philippines however destroyed everything that the immigrant Japanese had built. The former peaceful coexistence between the Filipinos and Japanese was replaced with a general hostility as some Japanese were harnessed to serve their country's armed forces. With the end of the war, the surviving Japanese residents were deported to Japan and whatever remained of their properties were vested by the government and sold to either the Filipinos or the Chinese. It would take decades before some Japanese would reestablish themselves in Manila but the great halcyon days of the prewar Japanese commercial community can never be restored. 
Appendix 1: Number of Japanese Businesses Operating in Manila as of December 31, 1937

Barbershops 11

book stores 1

jewelry stores 2

massage parlors 13

pomade factories 2

watch repair shops 7

plant nurseries 9

oil suppliers 1

footwear stores 1

bed factory 1

coal yard 1

shipyard 1

sun dries 1

dry cleaning shops 9 barbershops 11

neon lights 2

bank 1

restaurants 9

candy stores 2

groceries 4

automobile repairing 1

photographic studios 9

lumber export co. 1

sports goods stores 2

ice cream cup manufacturing plants 2

rubber goods factories. 1

marine supplies 4

Source: Bureau of Insular Affairs, Confidential Survey, Document No. 28876, December 31, 1037. 
Appendix 2: Vesting Order by the Philippine Government Seizing Japanese Properties in Manila

\section{Samples of Vesting Orders Seizing Japanese Properties in Manila after the Second World War}

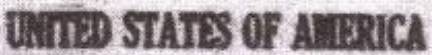

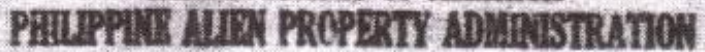

VEetrive ORBir No. R-128

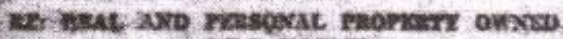
Ex. 2. Kosier

Unicior the ksithority or the Trading with the Enemy Ach as amended, the Philigpiae Yroperty Aet-of 1946, and Frecutive Oxtier

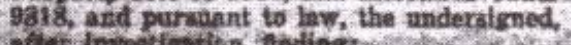
atter invoetigstion Nadiags

1. That $x$. Kowed, a Japasene saldect, wheae pres: ent wheresbouta ne unknown ad who is Buliered to be s moldent of Jikpen, lo a satlonal of = deolgated eacany esuntry (Jepen);

2. That the priperty deacribed as follaws:

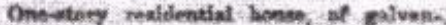
latd izon rooting, wooded thoor and stalinme. containing three-(3) roecre ba goot condithon and dexizmated as $\mathrm{Na}$ utz on Arlegel Btreet, San Migsel, Marila, Mhiliprines. cosatrueted on lot $\mathrm{Na}$. 24- A, Neek $\mathrm{Na}$.

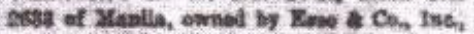
and perronal property cunsiveling of one thowende $(1,06)$ enrthes pets ane (1) lise bex of wood and two (2) woden tablex. all vecated within the prenisen,

Is properiy within the Plalippines asned or ecatrolited by, payable or idiverable to beld

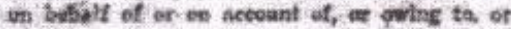

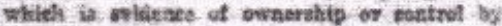
the afornatd national of a drsignated enemp couctey (Japan):

And determining that to the extent that such national is a person not within a desigusted eneroy country, the national inerest of the United States roguires that sach per. ton be treated as a national of a devignated emosny conintry (Japan):

Avd baving made an deterninations and takes all action required by law, Including appropriste consultstion and certification, and decaning it necessary in the national interest.

Hercer vTsts in the Philippine Alien Peoperty Adiministrator the property de scribed in sobperasrapb 2 hereof, subject to recorded liens, eneumbrances, and ether rights of record heid by or for pwrsons whe wro not nationals of dosignated enemy countries, to be held, used, administersd, Hqui- dated, sold or otherwibe dest with in th fnterest and for the beneffe of the Dnites States in accordanse win the provisions of the Trading with the Boerty Act, as amen

ed, and the thilippina Properts act of is: Any persous, except a tational of a desis: nated ebemy cogntion, ascerting any elsio

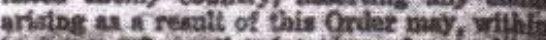

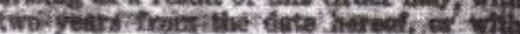
wuch further tinse al may be allowed, with the Philippise Alicn Property Adnify istrator on Form PAPA-1 a notice of elab together with a reguest far a bearin thereon. Nothing herein soutwined shain ?

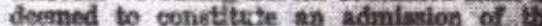

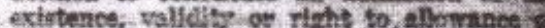
uny such claim.

Executed at Manila, Phllippines, on Apd so, 1917 .

$$
\text { JAMres MeT. HEmeraen }
$$
Phlippine Alion Property Adimininto

Fited with the Ometic Guerse on Aprit 9967, at 2.00 p. m

\section{Verrusio Oswera No. P-199}

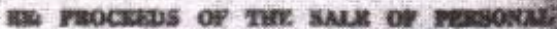

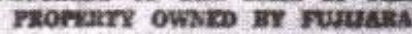

Ender the axthortly of the Trading wioh the Fnemy. Act, as amended, the Philipsine Property Act of 1946, and Executive Order $9 \$ 18$, and pursusert to las, the undersigncd. after investigation, finding:

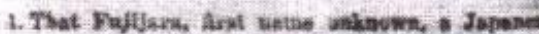

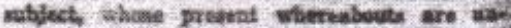

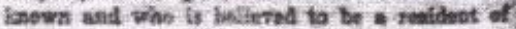
Japean, is a pationst of a devirratod enemy cosintry (Axpan) :

2. That the propirty described as followe: Tho rum of rogo nepresenting pereeclo from the exie by the Srimy Property Cuatudiaar teitud States Army, APO $20 \%$ of ceating machiners equipioent, ws tollows: 2-1rom Railurs whi gwar bores i-Siears belles, statlonary 1-Bmoke stack, irot, of, tha 2-Nixiag tarise, tras, $860-1,000 \mathrm{gal}$. espacity, 


\section{Notes}

${ }^{1}$ Yoko Yoshikawa, "Jose M. Tagawa and the Japanese Commercial Sector in Manila", Philippine Studies, Vol. 43, April-June 1995, p. 167.

${ }^{2}$ Motoe Terami Wada, "The Philippine Revolution and the Japanese Community in Manila", Paper read at the $17^{\text {th }}$ National Conference on Oral and Local History, Ateneo de Manila University, November 23-25, 1996, pp. 3-4.

${ }^{3}$ Yoko Yoshikawa, "Jose M. Tagawa and the Japanese Commercial Sector in Manila”, p. 169.

${ }^{4}$ Motoe Terami Wada, "Karayuki San”, Philippine Studies, No. 34, 1986, p. 296.

${ }^{5}$ Ibid.

${ }^{6}$ Milagros Guerrero, “Ä Survey of Japanese Trade and Investments in the Philippines with Special References to Philippine and American Relations, 1900-1941", Philippine Social Science and Humanities Review, Vol. 51, Mar. 1966, p. 33.

${ }^{7}$ Kiyoshi Osawa, (trans. and edited) Marivi Jugo Nañagas, The Japanese Commercial Community in the Philippines, Before, During and After the War, Manila: Joshu Bunko Library, 1994, p. 3.

${ }^{8}$ Ibid.

${ }^{9}$ Serafin D. Quiason, “The Japanese Community in Manila, 1898-1941”, Philippine Social Science and Humanities Review, Vol. 23, Nos. 2-4, 1958, p. 336.

${ }^{10}$ Yoko Yoshikawa, "Jose M. Tagawa and the Japanese Commercial Sector in Manila”, p. 85.

${ }^{11}$ Ibid., p. 185.

${ }^{12}$ Motoe Terami Wada, "Karayuki San”, p. 301

${ }^{13}$ Yoko Yoshikawa, "Jose M. Tagawa and the Japanese Commercial Sector in Manila”, p. 178.

${ }^{14}$ Motoe Terami Wada, “Karayuki San”, p. 23.

${ }^{15}$ Ibid., p. 51.

${ }^{16}$ Kiyoshi Osawa, (trans. and edited) Marivi Jugo Nañagas, The Japanese Commercial Community in the Philippines, Before, During and After the War, p. 62.

${ }^{17}$ Kaoru Watanabe, Watanabe, Kaoru, Philippine Japan Yearbook and Business Directory, Manila: 1935, p. 105.

${ }^{18}$ Ibid.

${ }^{19}$ Kaoru Watanabe, Watanabe, Kaoru, Philippine Japan Yearbook and Business Directory, p. 107.

${ }^{20}$ Yoko Yoshikawa, "Jose M. Tagawa and the Japanese Commercial Sector in Manila", pp. 175-176.

${ }^{21}$ Grant Goodman, “Äs if We were at Home: Japanese Economic Activity in the Philippines 1931-1941", Unpublished Manuscript, University of Kansas, p. 40.

${ }^{22}$ Lydia, N Yu-Jose, Japan Views the Philippines, Quezon City: Ateneo University Press, 1992, p. 123.

${ }^{23}$ Kiyoshi Osawa, Kiyoshi, Trans. Ruthie Aquino, A Japanese in the Philippines, Quezon City: 1981, pp. 238239. 